\title{
Parity Early Stage of Marriage with Incidence of Postpartum Depression
}

\author{
Eny Retna Ambarwati, Ria Listiyani
}

Midwifery Academy of Yogyakarta, Yogyakarta, Indonesia

\section{Article Info \\ Article history: \\ Received April 02, 2014 \\ Revised May 20, 2014 \\ Accepted Aug 25, 2014}

\section{Keyword:}

Parity

Early stage of marriage

Postpartum depression

\begin{abstract}
Postpartum depression is a condition that may be experienced by women. If it is not addressed properly, it will have a negative impact. The research aimend to determine the correlation between parity and the early stage of the marriage with the incidence of postpartum depression. This research employedanalytic observational method with cross sectional approach. The population in this research was postpartum mothers in Maternal Hospital Leonisa. The result showed that there was a correlation between parity and the early stage of the marriage with the incidence of postpartum depression.
\end{abstract}

\section{Corresponding Author:}

Eny Retna Ambarwati, Midwifery Academy of Yogyakarta,

Jl. Parangtritis Km 6, Sewon, Bantul, Yogyakarta.

Email: enyretna@gmail.com

\section{INTRODUCTION}

Postpartum depression is a condition that is possibly experienced by women in the postpartum period. From the previous research, it is noted that in Western countries, postpartum depression incidences experienced by approximately $15-20 \%$ of women in labour, either for the first time or for the next. In Malaysia, it is noted that mothers experiencing postpartum depression is $3.9 \%$, meanwhile in Singapore the number of incidence is only $1 \%$. The number of postpartum depression incidence in Indonesia only reaches an average of $11-30 \%$. If it is not addressed properly, it will give a negative impact for the mothers, the infants, and the families [1].

The causative factors of postpartum depression include biological, psychological, socio-cultural and age factors and many other factors that can lead to postpartum depression. Other causes of postpartum depression include the mothers' age which are too young or too old, the history of miscarriage, the parity or the number of the children, single mothers and birth trauma [2].

Age is one of the causal factors of postpartum depression. The majority of the community believes that the appropriate time for a woman to be in labour is between the age of 20 and 30 year-old because within that time, it is an optimal period to perform infant and family caring. The women's age factor during the pregnancy and the labour period is often associated with the women's mental readiness to become a mother.

If it seen viewed from the psychological aspect, women between the age 20 and 35 year-old have been mature in making the decision, and at this age, the productivity capability is sufficient, in contrast to women younger than 20 year-old who are still too young to be mothers and women older than 35 year-old who have too many psychosocial stressors [3].

According to the data obtained from the Religious Ministry of Yogyakarta in 2012, it can be concluded that the rate of underage marriages in Yogyakarta Province is still relatively high. GunungKidul Regency ranks first, i.e. in number of women with early marriage which is amounted to 37 women, followed 
by Bantul Regency which ranks second, i.e. as many as 30 women, in Yogyakarta City as many as 17 women, in Sleman Regency as many as 12 women, and in KulonProgo Regency as many as 2 women. Therefore, the writer subsequently performed a preliminary study in Leonisa Maternity Hospital, located in Wonosari, GunungKidul Regency.

The results from preliminary study that had been conducted in Leonisa Maternal Hospital, Wonosari, GunungKidul in January and February 2013 indicated that from the sample consisted of 10 patients who were used as the respondents, after a screening with Edinburgh Postnatal Depression Scale (EPDS) and questionnaires on the maternal age and the maternal parity, it was determined that 4 out of 10 respondents experienced depression symptoms, 7 respondents experienced multipara, 3 respondents experienced primipara, and 3 out of 10 respondents' age at their marriages were included in unhealthy reproductive ages, i.e. were younger than 20 year-old or older than 35 year-old.

\section{RESEARCH METHOD}

The type of the research was analytic observational study, i.e. a research method that describes the relationship existing between-variables by hypothesis testing [4]. Based on the time setting of the research, the design of this research used cross-sectional study because it studied the correlation between the risk and effect factors with "Point Time Approach" model which used one-time data collection quickly, as well as to describe individual's development in order to obtain complete data in a relatively short time, i.e. to determine the degree of postpartum depression in Leonisa Maternity Hospital, Wonosari, Gunung Kidul [5].

Population is a generalized region comprises of objects or subjects possessing certain quantities and characteristics established by the researcher to be studied and to be concluded subsequently [6]. The population in this research was all postpartum mothers in labour at Leonisa Maternity Hospital amounted to 61 postpartum. The samples were taken by purposive sampling with inclusion and exclusion criteria as the following:

1. Inclusion criteria in this research: postpartum from day $7^{\text {th }}$ to day $14^{\text {th }}$ in Leonisa Maternity Hospital, Wonosari, were willing to be respondents and were on site during the research.

2. The exclusion criteria in this research: postpartum in Leonisa Maternity Hospital, Wonosari suffering from morbidities or complications, such as bleeding, hypertension, postpartum with dead infants, postpartum with premature infants.

The independent variables in this research were parity and the age at the marriage. The dependent variables in this research were postpartum depression. The data analysis was performed by univariate and bivariate analysis. Chi-square test was done as bivariate analysis method ${ }^{\text {[7]. }}$

The research instrument used to examine the age and the parity in this research was questionnaires containing the identity, age, and maternal parity, meanwhile the measuring instrument to examine the postpartum depression incidence was Edinburgh Postnatal Depression Scale (EPDS) adopted from The British Journal of Psychiatry [8].

\section{RESULTS AND ANALYSIS}

\subsection{Univariate Analysis}

Univariate analysis includes variable analysis in the research, i.e. parity variable, the age at the marriage variable and postpartum depression incidence variable. Therefore, the amount or the frequency and the percentage can be viewed.

Table 1.The frequency distribution of the respondents based on the parity, the age at the marriage,

\begin{tabular}{|c|c|c|c|}
\hline No & Variable & Frequency & $\%$ \\
\hline \multirow[t]{5}{*}{1} & Parity & & \\
\hline & a. Primipara & 13 & 34 \\
\hline & Sekundipara & 14 & 47 \\
\hline & Multipara & 11 & 29 \\
\hline & d. Grandemultipara & 0 & 0 \\
\hline \multirow[t]{2}{*}{2} & The Age at the Marriage & & \\
\hline & $\begin{array}{l}\text { a. Healthy Reproductive Age } \\
\text { b. Unhealthy Reproductive Age }\end{array}$ & 26 & 68 \\
\hline \multirow[t]{3}{*}{3} & Postpartum Depression Incidence & & \\
\hline & $\begin{array}{l}\text { a. Normal } \\
\text { b. Depression Symptoms }\end{array}$ & 25 & 66 \\
\hline & Total & 38 & 100 \\
\hline
\end{tabular}


Table 1 shows the frequency distribution of the respondents based on the parity, the age at the marriage, and postpartum depression incidence in Leonisa Maternal Hospital, Wonosari. The table informs that that the majority of the respondents are sekundipara, i.e. as many as 14 people (47\%), the majority of the respondents who are in healthy reproductive age at the marriage are as many as 26 women (68\%), meanwhile the majority of respondents that is 25 women $(66 \%)$ do not experience postpartum depression or normal.

\subsection{Bivariate Analysis}

Bivariate analysis includes variable analysis in the research, i.e. parity variable with postpartum depression incidence, and the age at the marriage with postpartum depression incidence.

Table 2. The relationship between parity and postpartum depression incidence

\begin{tabular}{|c|c|c|c|c|c|c|c|c|}
\hline \multirow{3}{*}{ Parity } & \multicolumn{4}{|c|}{ Postpartum depression incidence } & & & \multirow{3}{*}{$x^{2}$ count } & \multirow{3}{*}{$P$ value } \\
\hline & \multicolumn{2}{|c|}{ Normal } & \multicolumn{2}{|c|}{$\begin{array}{l}\text { Depression } \\
\text { Symptoms }\end{array}$} & \multicolumn{2}{|c|}{ Total } & & \\
\hline & $\mathrm{n}$ & $\%$ & $\mathrm{n}$ & $\%$ & $\mathrm{n}$ & $\%$ & & \\
\hline Primipara & 2 & 5 & 11 & 29 & 13 & 34 & 22,864 & 0,00 \\
\hline Sekundipara & 12 & 32 & 2 & 5 & 14 & 37 & & \\
\hline Multipara & 11 & 29 & 0 & 0 & 11 & 29 & & \\
\hline Grandemultipara & 0 & 0 & 0 & 0 & 0 & 0 & & \\
\hline Total & 25 & 66 & 13 & 34 & 38 & 100 & & \\
\hline
\end{tabular}

From Table 2, it can be seen that from 38 respondents, the result obtained is that the majority of the respondents are sekundipara and do not experience postpartum depression symptoms or normal, i.e. as many as 12 women (32\%), meanwhile those experiencing depression symptoms are majorly primipara, i.e. as many as 11 women (29\%).

After the data analysis was conducted, x2 count is obtained by 22.864 and p value 0.00 with $2 \mathrm{df}$ significance level of 5\% (0.05) x table of 5.591. Therefore, it can be concluded that the p value is less than 0.05 and $\mathrm{x} 2$ count is greater than $\mathrm{x}$ table, thus Ho is rejected and Ha is accepted, which means that there is a relationship between the parity and postpartum depression incidence in Leonisa Maternity Hospital, Wonosari.

Parity is the number of live births which are experienced by a woman [9]. The parity will affect a woman's psychology in performing their role as a mother. However, how much of the impact is yet unknown because of each person's psychology is diverse and is influenced by many factors. Postpartum disorders are associated with parity status, i.e. the patients' obstetric history including the history of pregnancy until the labour period as well as whether there are complications of the previous pregnancy and the labour, It occurs more often in primipara women. Primipara women suffer from depression more commonly because in postnatal period, primipara women are in the adaptation process $^{10}$. Physical changes after the labour process and the heightening of mental disorders during the first two weeks indicates that physical factors which are associated with the first labour, are important factors. Hormonal changes occur drastically in postnatal period and latency period during the two days between the labour and the appearance of the symptoms. These changes greatly affect the balance, especially drastic changes in progesterone and estrogen hormones in postnatal period. The parity or the number of the children also affects on mothers' psychology in carrying out their roles as mothers [10].

A rapid transition from the state of "two in one" at the end of the pregnancy to become two individuals, i.e. the mothers and the children depend on the individual's psychological adjustment. The importance of love in preventing this transition period is to start a good relationship between the mothers and children.

Parity has a relationship with postpartum depression incidence. One of the factors influencing postpartum depression is parity. Parity affects on postpartum depression incidence. A mother who only has one child is certainly less in experiences compared to a mother with two or more children. Mothers who only have one child are less likely to know how to care for the infants as well as for themselves who have transitioned their roles as mothers.

The number of primipara at Leonisa Maternity Hospital after the research was conducted; 11 respondents experiencing depression symptoms compared to sekundipara that only consisted of 2 respondents (5\%), whereas in multiparous, none had depression symptoms. It proves that primipara indeed tends to be more susceptible to experience postpartum depression symptoms. The recearch 
different with recearch from janica wisart, 2005 employment, parity did not seem to have any effect in producing depression [11].

Table 3. The relationship between the age at the marriage and postpartum depression incidence

\begin{tabular}{|c|c|c|c|c|c|c|c|c|}
\hline \multirow{3}{*}{ The Age at the Marriage } & \multicolumn{4}{|c|}{ Postpartum depression incidence } & & & \multirow{3}{*}{$x^{2}$ count } & \multirow{3}{*}{$P$ value } \\
\hline & \multicolumn{2}{|c|}{ Normal } & \multicolumn{2}{|c|}{$\begin{array}{l}\text { Depression } \\
\text { Symptoms }\end{array}$} & \multicolumn{2}{|c|}{ Total } & & \\
\hline & $\mathrm{n}$ & $\%$ & $\mathrm{n}$ & $\%$ & $\mathrm{~N}$ & $\%$ & & \\
\hline Healthy Reproductive Age & 22 & 58 & 4 & 10 & 26 & 68 & 12,965 & 0,00 \\
\hline Unhealthy reproductive age & 3 & 8 & 9 & 24 & 12 & 32 & & \\
\hline Total & 25 & 66 & 13 & 34 & 38 & 100 & & \\
\hline
\end{tabular}

From Table 3, it can be seen that the majority of respondents get married at healthy reproductive age and they do not experience postpartum depression symptoms (normal), i.e. as many as 22 respondents (58\%), whereas those experiencing postpartum depression symptoms are majority got married at unhealthy reproduction age, i.e. s many as 9 respondents (24\%).

After being analyzed, x2 is obtained at 12.965 and p value at 0.00 with significance level $\mathrm{df}$ 1 at $5 \%$ and $x$ table at 3.481. Therefore, it can be concluded that the p value is less than 0.05 and $x 2$ count is greater than $\mathrm{x}$ table, thus, Ho is rejected and Ha is accepted, which means that there is a relationship between the age at the marriage with the postpartum depression incidence in Leonisa Maternity Hospital, Wonosari.

The age at the marriage highly affects a woman's psychology. If a woman gets married at the age younger than 20 year-old, the experience is certainly insufficient and her psyche is less than mature. If the condition is coupled with the pregnancy and labour condition that automatically changes the role to be a wife and a mother, it certainly needs a fast process of adaptation or adjustment.

This condition is in contrast to women who get married between the ages of 20 year-old to 35 year-old. If being seen from the psychological aspect, women at the age of 20-35 year-old are mature enough in taking decision and within this age, the productivity capabilities are sufficient. In contrast to women younger than 20 year-old who are still too young and women older than 35 year-old who too many psychosocial stressors [8].

The age at the marriage is the age when a woman gets married and it means that she is ready to experience pregnancy and labour period. The best time for a woman to get pregnant and go into labour ranges is from the age of 20 to 35 year-old. High-risk pregnancy emerges in women who become pregnant at the age younger than 20 year-old or older than 35 year-old, have delivered four children or more, and the interval or the distance is less than two years [10],[14].

The effects of psychosocial factors, socioeconomic factors, relevant demographical data (number of family members, age) because these factors are likely to influence the results depresi postpartum. Such changes could predispose women to develop depression to a certain degree, suggesting a time-specific threshold might be appropriate [12]-[14]. The WHO has advised that health policy integrate mental health care into primary health care settings [15]. Although further research is needed to establish the scalability and effectiveness of interventions for depression in community contexts, this study provides an important step in documenting the need for antenatal screening for depression [16].

\section{CONCLUSION}

The majority of respondent: was sekundipara (47\%); got marriage in healthy reproductive age (68\%); did not experience popspartum depression symptoms (66\%). There was a significant relationship between the parity and the age at the marriage with postpartum depression incidence in Leonisa Maternity Hospital, Wonosari.

\section{REFERENCES}

[1] Elvira, S., “Depresi Pasca Persalinan”, Jakarta: FKUI, 2006.

[2] Wulandari, Handayani, “Asuhan Kebidanan Ibu Masa Nifas”, Yogyakarta: GosyenPublising, 2011.

[3] Maramis, W.F., “Catatan Ilmu Kedokteran Jiwa”, Surabaya: Airlangga University Press, 2005.

[4] Notoatmodjo, S., "Metodologi Penelitian Kesehatan”, Jakarta: RinekaCipta, 2005.

[5] Sugiyono, “Metode Penelitian Kuantitatif Kualitatif dan R\&D”, Bandung: Alfabeta, 2009.

[6] Saryono, "Metodologi Penelitian Kebidanan”, Jakarta: Nuha Medika, 2010. 
[7] Sugiyono, “Statistik Untuk Penelitian”, Bandung: Alfabeta, 2002.

[8] BKKBN, “Deteksi Dini Komplikasi Persalinan”, Jakarta: BKKBN, 2006.

[9] Rukiyah, dkk., “Asuhan Kebidanan IV (Patologi Kebidanan)”, Yogyakarta: Trans Info Media, 2010.

[10] Hartanto, "Family Planning and Contraception”, Jakarta: Pustaka Sinar Harapan, 2004.

[11] Janice Wissart, Omkar Parshad and Santosh Kulkarni, "Prevalence of pre- and postpartum depression in Jamaican women”, BMC Pregnancy Childbirth, 2005. Nov 8 : 10.1186/1471-2393-5-15.

[12] Norika Hayakawa et al., "The Postpartum Depressive State in Relation to Perceived Rearing: A Prospective Cohort Study”, PLoS One, 2012. Nov 21: 10.1371.

[13] Su KP, Chiu TH, Huang CL, Ho M, Lee CC, et al., "Different cutoff points for different trimesters? The use of Edinburgh Postnatal Depression Scale and Beck Depression Inventory to screen for depression in pregnant Taiwanese women”, Gen Hosp Psychiatry, vol. 29, pp. 436-441, 2007.

[14] Klainin P and Arthur DG., "Postpartum depression in Asian cultures”, a literature Pubmed gov rev Oct, pp. 135573, 2009.

[15] Faisal-Cury A, Menezes P, Araya R, Zugaib M., "Common mental disorders during pregnancy: Prevalence and associated factors among low-income women in Sao Paulo, Brazil: depression and anxiety during pregnancy”, Arch Womens Ment Health, pp. 335-343, 2005.

[16] Mary Hartley et all., "Depressed mood in pregnancy: Prevalence and correlates in two Cape Town peri-urban settlements”, Reproductive Health, 2011. 10.1186/1742-4755-8-9. 